\title{
Economic Growth and Unemployment Relationship: An Empirical Study for MENA Countries
}

\author{
Dr. Ibrahim khrais, Prof. Dr. Mahmoud Al-Wadi
}

Faculty of Economics and Administrative Sciences, Zarqa University, Jordan

\begin{abstract}
The main purpose of this paper is to examine the relationship between GDP growth and unemployment in MENA countries for the period (1990-2016) periods. Simple linear regression used for the analyses. The results indicated that the impact values considered by GDP on the Unemployment in all the countries being involved. The significance level of $(F)$ was greater than $(\alpha=0.05)$ suggesting no significant impact was observed for gross GDP (annual) representing all the countries being involved in the study on Unemployment in all the countries calculated from labours numbers in these countries. The impact value is considered to be very small (-0.009). This value suggests that there may be other factor affecting unemployment other than GDP.
\end{abstract}

Keywords: Unemployment, Economic growth, GDP, MENA countries.

\section{INTRODUCTION}

Unemployment is regarded as a serious problem faced most developed and developing countries and resulting socio-economic problems. The governments have given great attention to create job opportunities and reoperation the idle units to eliminate this phenomenon.

There are several reasons behind this phenomenon, especially in the developing countries, it is attributed to the shortage of the economic growth accompanying with incremental population, inability to mobilize domestic savings in financing desired investments, decline in economic activity due to recession, changes in technology, changes in consumer demand, on-qualifying employment, which are not commensurate with the changes in labour market. Unemployment usually comes as a result of disequilibrium between demand and supply in the labour market.

It is a widely accepted view that the growth rate of GDP directly affects employment. If it rises, then employment will rise and the unemployment rate will fall. Many studies confirm the existence of a trade-off between economic growth and change rates of unemployment prevailing in the economy.

The main purpose of this paper is to examine the relationship between unemployment and GDP growth in MENA countries. The study is structured into 3 sections: section (1) deals with the literature review; section (2) discusses methodology and data; while analysis of results, conclusion and recommendations are presented in section (3).

\section{LITERATURE REVIEW}

The negative correlation between economic growth and unemployment was first stressed by Okun (1962). Following studies have mostly proposed evidence that is parallel to Okun's study. It is possible to group these studies in the literature into two. First group of studies establishes a symmetrical tie between economic growth and unemployment and the second group which also includes the recent studies discusses asymmetrical relationship between unemployment and economic growth. In most of the studies that support asymmetrical relationship between economic growth and unemployment, the main idea is that economic growth and unemployment relationship is more intense in the economic downturn periods compared to economic expansion periods. And he proposed that an negative relationship existed between real output level and unemployment level in his study in which he used data obtained from U.S. economy. Eventually, this idea was accepted as Okun's law in the economics theory and it assumed that in the periods when the economic growth is over 2, 25\%, each $1 \%$ increase in real output level caused $0,5 \%$ reduction in unemployment rate. 
- Cuaresma (2003) proposed an asymmetrical relationship between unemployment and economic growth in his study in which he used US economic data. The author found significant relationship between economic growth and unemployment during economic shrinkage periods.

- Silvapulle et al. (2004) stressed that the effect of economic growth over unemployment was more significant during the time of economic shrinkage in his study in which he used US economic data between 1947 and 1999.

- Lee (2000) discussed existence of a strong relationship between economic growth and unemployment in his study which supported Okun's law and was conducted for 16 OECD countries.

- Malley and Molana (2008) used quarterly data for G7 countries between the years of 1960 to 2001 and they stated that the relationship between economic growth and unemployment was more significant in the case of Germany.

- Pierdzioch et al. (2011) tested whether professional economists' forecasts of changes in the unemployment rate and the growth rate of real output were consistent with Okun's law for the period 1989-2007 for G7 and found the growth rate of real output and unemployment rate were consistent with Okun's law.

- Owyang and Sekhposyan (2012) investigated the degree of time variation in the unemployment and output fluctuations over the business cycle for U.S. case. They found a great degree of instability in the historical performance of Okun's law. The breakdowns in Okun's law seemed to be highly correlated with the business cycle. The detected break dates of the largest changes the coefficients appeared to be around recessions.

- Bankole and Fatai (2013) estimated the Okun's coefficient, and checked the validity of Okun's law in Nigeria, using the time series annual data during the period 1980-2008. Engle granger cointegration test and Fully Modified OLS were employed. The empirical evidences showed that there is positive coefficient in the Regression, implying that Okun's law interpretation is not applicable to Nigeria. It was recommended that government and policy makers should employ economic policies that are more oriented to structural changes and reform in labour market.

- Ball, Leigh, and Loungani (2012) asked how well Okun's Law fits short-run unemployment movements in the United States since 1948 and in twenty advanced economies since 1980. And found that Okun's Law is a strong and stable relationship in most countries, one that did not change substantially during the Great Recession. Accounts of breakdowns in the Law, such as the emergence of "jobless recoveries," are flawed. Also found that the coefficient in the relationship - the effect of a one percent change in output on the unemployment rate- varies substantially across countries. This variation is partly explained by idiosyncratic features of national labour markets, but it is not related to differences in employment protection legislation.

- Irfan Lal et al. (2010) estimated the Okun's coefficient, and checked the validity of Okun's law in some Asian countries, for this purpose they used the time series annual data during the period 19802006. Engle Granger (1987) co integration technique is employed to find out long run association between variables and error correction mechanism (ECM) is used for short run dynamic. After getting empirical evidences it can be said that Okun's law interpretation may not be applicable and also the principle of NAIRU does not hold its validity in some Asian developing countries.

- Noor, Nor and Judhiana (2007) examined whether there exist an Okun - type relationship between output and unemployment in the Malaysian economy. The empirical results show that there was an inverse relationship between output and unemployment.

- Naimy (2005) applied Okun-type relationship to the Lebanese equation in order to estimate the Lebanese potential output. An empirical study covering 400 households is carried out to investigate the employment status using the BLS criterion in determining the most useful measures of the labour market. The main finding was that the impact of unemployment in Lebanon seems to be extremely harmful: the economy is $\$ 32$ billion below its potential output. Unemployment in Lebanon is continuously growing as a result of the present financial and economic27 - deadlockll situation. It is the human resources of a nation, not its physical capital or its natural resources, that ultimately determine the character and pace of its economic growth and social development. Capital and natural 
resources are passive 28 factors of production; human beings are the active agents who accumulate capital, exploit natural resources, build social, economic and political organizations, and carry forward national development. Clearly, a country which is unable to develop the skills and knowledge of its people and to utilize them effectively in the national economy, will be unable to develop anything else.

- Studies that examine the relationship between real economic growth and unemployment such as Harris ve Silverstone (2001), Sögner and Stiassny (2002), Huang and Lin (2008), Villaverdeve Maza (2009), Meyer veTaşçı (2012), Huang and Yeh (2013) generally support the inverse relationship between economic growth and unemployment but the strength of relationship between economic growth and unemployment in the studies differ greatly depending on the sample and the context explored.

\section{Data Set \& Methodology}

The study has identified effective variables to analyse unemployment, gross domestic product in MENA countries for the period (1990-2016) periods by reviewing the literature. The variables have been obtained from World Bank data bases. As in all time series analyses, variables of panel data analyses which processes both time and cross section analysis together need to be fixed to prevent fake relationship among the variables. Simple linear regression used for the analyses.

\section{EMPIRICAL RESULTS}

Table1. Means, standard deviations and skewness for GDP (annual)in each country for the period (1990 -2016)

\begin{tabular}{|c|c|c|c|c|}
\hline Country & N & Mean & Std. & Skewness \\
\hline Algeria & 26 & 3.05 & 1.84 & 0.10 \\
\hline Bahrain & 26 & 5.12 & 2.74 & 1.10 \\
\hline Egypt, Arab Rep. & 26 & 4.22 & 1.66 & 0.00 \\
\hline Iran, Islamic Rep. & 26 & 4.23 & 3.81 & 0.97 \\
\hline Iraq & 26 & 12.82 & 16.31 & 1.68 \\
\hline Jordan & 26 & 5.00 & 3.56 & 2.39 \\
\hline Kuwait & 26 & 5.15 & 7.39 & 2.67 \\
\hline Lebanon & 26 & 6.48 & 8.36 & 2.86 \\
\hline Libya & 26 & 2.14 & 3.79 & 1.87 \\
\hline Mauritania & 26 & 4.13 & 4.23 & 1.74 \\
\hline Morocco & 26 & 4.35 & 3.15 & 0.67 \\
\hline Oman & 26 & 3.89 & 2.55 & -0.16 \\
\hline Qatar & 26 & 6.36 & 7.88 & 1.13 \\
\hline Saudi Arabia & 26 & 4.35 & 3.18 & 0.20 \\
\hline Sudan & 26 & 5.15 & 3.15 & 0.12 \\
\hline Syrian Arab Republic & 26 & 3.78 & 3.60 & 0.61 \\
\hline Tunisia & 26 & 4.11 & 2.09 & 0.09 \\
\hline Turkey & 26 & 4.89 & 3.31 & -0.25 \\
\hline United Arab Emirates & 26 & 5.17 & 4.09 & 1.38 \\
\hline Yll countries & 26 & 3.94 & 2.14 & -0.46 \\
\hline
\end{tabular}

Table (1) indicates the mean values, standard deviations and skewness for GDP (annual) in each country. It's noted that Iraq had the largest GDP (12.82) during the time period (1990 -2016) followed by Lebanon (6.48) then by Qatar (6.36), while Algeria is the country who had the least GDP during this period (3.05).

The overall GDP (annual) being monitored in the countries involved in this study was (5.11)

The last column in the table indicates the skewness values for GDP variable specified for each country. It was observed that all the mentioned skewness values is considered to be close to the normal distribution of data as the acceptable values generally accepted if it ranged between (-3) and $(+3)$ other studies accept skewness values if it ranged between $(-1)$ and $(+1)$. 
Table2. Means, standard deviations and skewness for unemployment (\% of labours)in each country for the period (1990-2016)

\begin{tabular}{|c|c|c|c|c|}
\hline Country & N & Mean & Std. & Skewness \\
\hline Algeria & 26 & 17.85 & 8.78 & -0.46 \\
\hline Bahrain & 26 & 3.84 & 1.21 & -2.56 \\
\hline Egypt, Arab Rep. & 26 & 9.39 & 3.13 & -2.07 \\
\hline Iran, Islamic Rep. & 26 & 11.16 & 3.39 & -3.01 \\
\hline Iraq & 26 & 17.15 & 6.18 & -1.18 \\
\hline Jordan & 26 & 12.98 & 4.37 & -1.94 \\
\hline Kuwait & 26 & 1.39 & 0.97 & 1.01 \\
\hline Lebanon & 26 & 7.08 & 2.30 & -2.42 \\
\hline Libya & 25 & 17.69 & 5.23 & -3.03 \\
\hline Mauritania & 26 & 29.40 & 8.67 & -3.05 \\
\hline Morocco & 26 & 10.98 & 3.97 & -1.49 \\
\hline Oman & 26 & 6.83 & 2.07 & -3.03 \\
\hline Qatar & 26 & 0.54 & 0.35 & 0.96 \\
\hline Saudi Arabia & 26 & 5.17 & 1.62 & -2.70 \\
\hline Sudan & 26 & 13.69 & 4.03 & -3.06 \\
\hline Syrian Arab Republic & 26 & 8.69 & 2.95 & -2.01 \\
\hline Tunisia & 26 & 13.57 & 4.27 & -2.64 \\
\hline Turkey & 26 & 8.52 & 3.06 & -1.51 \\
\hline United Arab Emirates & 26 & 2.94 & 1.07 & -1.55 \\
\hline Yemen, Rep. & 26 & 13.69 & 4.41 & -2.42 \\
\hline All countries & 26 & 10.63 & 3.17 & -3.01 \\
\hline
\end{tabular}

Table (2) indicates the mean values, standard deviations and skewness for unemployment (\% of labours) in each country. It's noted that Mauritania had the largest unemployment (29.40) during the time period (1990 -2016) followed by Algeria (17.85) then by Libya (17.69) while is the Qatar country who had the least unemployment during this period (0.54).

The overall unemployment ( $\%$ of labours) being monitored in the countries involved in this study was (10.63).

The last column in the table indicates the skewness values for unemployment variable specified for each country. It was observed that all the mentioned skewness values is considered to be close to the normal distribution of data as the acceptable values generally accepted if it ranged between $(-3)$ and $(+3)$ other studies accept skewness values if it ranged between $(-1)$ and $(+1)$.

Table3. Simple linear regression to measure the impact of GDP (annual) on unemployment (\% of labours) in the countries of MENA countries

\begin{tabular}{|c|c|c|c|c|c|c|c|c|}
\hline Country & $\mathbf{r}$ & $\mathbf{R}^{2}$ & $\mathbf{F}$ & Sig. $\mathbf{F}$ & $\boldsymbol{\beta}$ & $\mathbf{t}$ & Sig. t & Result \\
\hline Algeria & 0.137 & 0.019 & 0.45 & 0.506 & 0.653 & 0.67 & 0.506 & $\mathrm{NS}$ \\
\hline Bahrain & 0.344 & 0.118 & 3.22 & $0.08 / 5$ & 0.152 & 1.79 & 0.085 & $\mathrm{NS}$ \\
\hline Egypt, Arab Rep. & 0.397 & 0.158 & 4.49 & $0.045^{*}$ & -0.747 & -2.11 & $0.045^{*}$ & $\mathrm{~S}$ \\
\hline Iran, Islamic Rep. & 0.219 & 0.048 & 1.21 & 0.282 & -0.195 & -1.10 & 0.282 & $\mathrm{NS}$ \\
\hline Iraq & 0.072 & 0.005 & 0.12 & 0.727 & -0.027 & -0.35 & 0.727 & $\mathrm{NS}$ \\
\hline Jordan & 0.407 & 0.166 & 4.77 & $0.039^{*}$ & -0.501 & -2.18 & $0.039^{*}$ & $\mathrm{~S}$ \\
\hline Kuwait & 0.044 & 0.002 & 0.04 & 0.832 & 0.006 & 0.21 & 0.832 & $\mathrm{NS}$ \\
\hline Lebanon & 0.184 & 0.034 & 0.83 & 0.369 & -0.050 & -0.91 & 0.369 & $\mathrm{NS}$ \\
\hline Libya & 0.093 & 0.009 & 0.20 & 0.652 & 0.024 & 0.45 & 0.652 & $\mathrm{NS}$ \\
\hline Mauritania & 0.287 & 0.0 .82 & 2.14 & 0.156 & 0.588 & 0.28 & 0.156 & $\mathrm{NS}$ \\
\hline Morocco & 0.042 & 0.002 & 0.04 & 0.837 & 0.053 & 0.04 & 0.837 & $\mathrm{NS}$ \\
\hline Oman & 0.162 & 0.026 & 0.64 & 0.428 & 0.132 & 0.806 & 0.428 & $\mathrm{NS}$ \\
\hline Qatar & 0.325 & 0.106 & 2.83 & 0.105 & 0.015 & 1.68 & 0.105 & $\mathrm{NS}$ \\
\hline Saudi Arabia & 0.010 & 0.00 & 0.002 & 0.962 & 0.005 & 0.048 & 0.962 & $\mathrm{NS}$ \\
\hline Sudan & 0.336 & 0.113 & 3.05 & 0.093 & 0.431 & 1.74 & 0.093 & $\mathrm{NS}$ \\
\hline Syrian Arab Republic & 0.132 & 0.018 & 0.42 & 0.519 & -0.108 & -0.65 & 0.519 & $\mathrm{NS}$ \\
\hline Tunisia & 0.071 & 0.005 & 0.12 & 0.731 & -0.145 & -0.348 & 0.731 & $\mathrm{NS}$ \\
\hline Turkey & 0.127 & 0.016 & 0.39 & 0.538 & -0.117 & -0.62 & 0.538 & $\mathrm{NS}$ \\
\hline United Arab Emirates & 0.520 & 0.270 & 8.87 & $0.007^{*}$ & -0.136 & -2.97 & $0.007 *$ & $\mathrm{~S}$ \\
\hline Yemen, Rep. & 0.306 & 0.093 & 2.47 & 0.129 & 0.630 & 1.57 & 0.129 & $\mathrm{NS}$ \\
\hline
\end{tabular}

S: It means significant, NS: It means not significant 
Table (3) suggest the impact values considered by GDP on the Unemployment in each country of the countries being involved. Only the probability values of $\mathrm{f}$ test tell that GDP affects Unemployment in significantly $(\mathrm{p}<0.05)$ in Egypt Arab republic where the impact value which expressed by $\beta$ coefficient was (- 0.747), in Jordan (0.501), and united Arab imarets (- 0.136). The results showed that the other countries had no impact of GDP on unemployment according to the significance values related to ANOVA and $(\mathrm{F})$ results which were $>0.05$ as mentioned in the table.

Table4. Simple linear regression to measure the impact of GDP (annual) on unemployment (\% of labours) in the countries of MENA countries

\begin{tabular}{|c|c|c|c|c|c|c|c|c|}
\hline Independent variable & $\mathbf{r}$ & $\mathbf{R}^{2}$ & $\mathbf{F}$ & Sig. F & $\boldsymbol{\beta}$ & $\mathbf{t}$ & Sig. t & Result \\
\hline GDP & 0.006 & 0.000 & 0.001 & 0.977 & -0.009 & -0.029 & 0.977 & NS \\
\hline
\end{tabular}

Table (4) suggest the impact values considered by GDP on the Unemployment in all the countries being involved. The significance level of $F$ was greater than $(\alpha=0.05)$ suggesting no significant impact was observed for gross GDP (annual) representing all the countries being involved in the study on Unemployment in all the countries calculated from labours numbers in these countries. The impact value is considered to be very small (- 0.009). This value suggests that there may be other factor affecting unemployment other than GDP.

\section{CONCLuSion}

- Unemployment is regarded as a serious problem faced most developed and developing countries and resulting socio-economic problems. The governments have given great attention to create job opportunities and reoperation the idle units to eliminate this phenomenon.

- The main purpose of this paper is to examine the relationship between unemployment and GDP growth in MENA countries. The study is structured into 3 sections: section (1) deals with the literature review; section (2) discusses methodology and data; while analysis of results, conclusion and recommendations are presented in section (3).

- The results indicated that the impact values considered by GDP on the Unemployment in all the countries being involved. The significance level of (F) was greater than $(\alpha=0.05)$ suggesting no significant impact was observed for gross GDP (annual) representing all the countries being involved in the study on Unemployment in all the countries calculated from labours numbers in these countries. The impact value is considered to be very small (-0.009). This value suggests that there may be other factor affecting unemployment other than GDP

\section{ACKNOWLEDGEMENT}

This research is funded by the Deanship of Research and Graduate Studies in Zarqa University

\section{REFERENCES}

[1] Harris, Ricard, Silverstone, Brian (2001), "Testing for Asymmetry in Okun's Law: CrossCountry Comparison”, Economics Bulletin, 5(2): 1-13.

[2] Huang, Ho-Chuan, Lin, Shu-Chin (2008), "Smooth-Time-Varying Okun's Coefficients", Economic Modelling, Vol. 25: 363-375.

[3] Huanng, Ho-Chuan, Yeh, Chih-Chuan (2013), "Okun's Law in Panels of Countries and States", Applied Economics, 45, Routledge, Taylor \& Francis Group, pp. 191-199.

[4] Irfan Lal et al. (2010) Test of Okun's Law in some Asian Countries: Co-integration Approach, European Journal of Scientific Research, 40 (1).

[5] Lee, Jim (2000), “The Robustness of Okun's Law: Evidence from OECD Countries”, Journal of Macroeconomics, 22(2): 331-356.

[6] Malley, Jim, Molana Hassan (2008), “Output, Unemployment and Okun's Law: Some Evidence from the G7”, Economics Letters, 101(2): 113-115.

[7] Meyer, Brent, Tasci, Murat (2012), “An Unstable Okun's Law, Not The Best Rule of Thumb”, Economic Commentary, Number 2012-08, Federal Reserve Bank of Cleveland, Cleveland, Ohio, United States of America, pp.1-6.

[8] Noor ZalehaMohd, Nor Norashidah Mohamad \& Judhiana Abdul Chani (2007). The relationship between output and unemployment in Malaysia: Does Okun's law exist? International Journal of Economics and Management, Vol. 3: 337-344. 
[9] Naimy V. (2005), Unemployment in Lebanon: Application of Okun's Law. The Journal of Business \& Economics Research, 3(10): 25-32.

[10] Okun, Arthur M. (1962), "Potential GNP: Its Measurement and Significance", Cowles Foundation Paper Vol. 19:1-7.

[11] Owyang, Michael T. and Sekhposyan, Tatevik (2012), “Okun's Law Over the Business Cycle: Was the Great Recession All That Different?", Federal Reserve Bank of St. Louis REVIEW, 94 (5): 399-418.

[12] Pierdzioch, Christian, Rülke, Jan-Christoph and Stadtmann, Georg (2011), "Do Professional Economists' Forecasts Reflect Okun's Law? Some Evidence for the G7 Countries", Applied Economics, Vol. 43: 1365-1373.

[13] Silvapulle, Paramsothy, MoosaImad A. and Silvapulle Mervyn J. (2004), “Asymmetry in Okun's Law", The Canadian Journal of Economics, 37(2): 353-374.

[14] Sögner, Leopold, Stiassny, Alfred (2002), “An Analysis on the Structural Stability of Okun's Law-A Cross Country Study”, Applied Economics, No.14: 1775-1785.

[15] Villaverde, Jose, Maza Adolfo (2009), "The Robustness of Okun's Law in Spain, 1980-2004 Regional Evidence", Journal of Policy Modeling, 31(2): 289-297. 